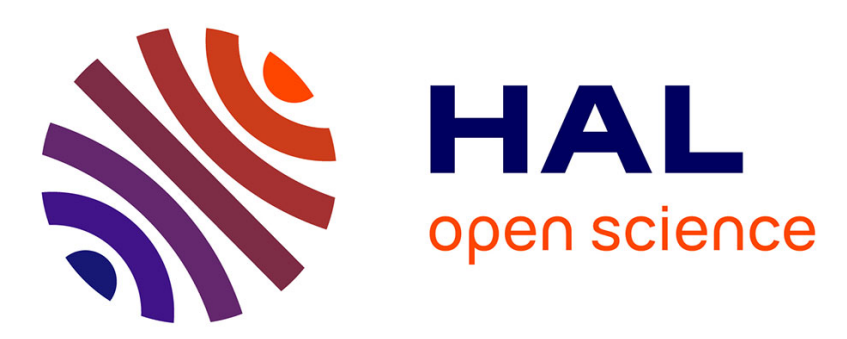

\title{
Stimulation of spermiation and induction of ovulation in pike (Esox lucius)
}

Roland Billard, Jacqueline Marcel

\section{To cite this version:}

Roland Billard, Jacqueline Marcel. Stimulation of spermiation and induction of ovulation in pike (Esox lucius). Aquaculture, 1980, 21 (2), pp.181-195. 10.1016/0044-8486(80)90027-7 . hal-01601675

\section{HAL Id: hal-01601675 \\ https://hal.science/hal-01601675}

Submitted on 2 Jun 2020

HAL is a multi-disciplinary open access archive for the deposit and dissemination of scientific research documents, whether they are published or not. The documents may come from teaching and research institutions in France or abroad, or from public or private research centers.
L'archive ouverte pluridisciplinaire HAL, est destinée au dépôt et à la diffusion de documents scientifiques de niveau recherche, publiés ou non, émanant des établissements d'enseignement et de recherche français ou étrangers, des laboratoires publics ou privés.

\section{다(1) (2)}

Distributed under a Creative Commons Attribution - ShareAlikel 4.0 International 


\title{
STIMULATION OF SPERMIATION AND INDUCTION OF OVULATION IN PIKE (ESOX LUCIUS)
}

\section{R. BILLARD* and JACQUELINE MARCEL*1}

* Laboratoire de Physiologie des Poissons, I.N.R.A., 78350 Jouy-en-Josas (France)

1 E.P.H.E., Laboratoire d'étude du développement post-embryonnaire des vertébrés inférieurs, 25, rue du Plat, 69288 Lyon Cedex I (France)

(Accepted 25 December 1979)

\author{
ABSTRACT \\ Billard, R. and Marcel, J., 1980. Stimulation of spermiation and induction of ovulation in \\ pike (Esox lucius). Aquaculture, 21:181-195.
}

Mature northern pike were given various hormonal treatments in March or April in order to stimulate spermiation or to induce ovulation. In males the total amount of sperm collected after treatment increased, in comparison with saline-injected males, by 3-11 times with partially purified salmon gonadotropin (PPSG-activity:half of the highly purified s-GTH; injected at doses of between 5 and $100 \mu \mathrm{g} / \mathrm{kg}$ body weight);3-6 times with crude carp pituitary extract $(0.5-3 \mathrm{mg} / \mathrm{kg}$ body weight); and $3-7$ times with fresh pike pituitaries (14 and $1.2 \mathrm{mg}$ wet weight $/ \mathrm{kg}$ body weight). The sperm obtained after hormonal treatment was of good quality. Intracardiac injection of superactive LRH analogue had no effect. In females, PPSG induced 90 and $100 \%$ ovulation at the doses of 50 and $25 \mu \mathrm{g} /$ $\mathrm{kg}$ body weight. Dried salmon pituitaries $(2.5 \mathrm{mg} / \mathrm{kg}$, equivalent to $50 \mu \mathrm{g}$ of PPSG) gave $25 \%$ ovulation; at $10 \mathrm{mg} / \mathrm{kg}, 25 \%$ complete ovulation was again recorded, but in addition $70 \%$ of the females showed oocyte maturation and partial ovulation. Similarly, dried carp pituitary $(3 \mathrm{mg} / \mathrm{kg}$ ) induced only oocyte maturation but no ovulation. The oocytes obtained after hormonal treatment were in general fertile. Intraperitoneal injection of LRH in an emulsified form induced neither oocyte maturation nor ovulation. The lack of effect of LRH analogue is discussed and shows that the use of this compound as a substitute for pituitary preparation is not very promising.

\section{INTRODUCTION}

Due to drastic changes in the natural environment such as the embankment of rivers and suppression of flooding areas in some rivers in France the pike now rarely reproduces naturally. Sport fishery for this species is therefore declining in such rivers and production of hatchery fry for stocking natural waters is required. Reliable ways of obtaining gametes are required in hatchery fry production. In most European and American hatcheries brood stock is collected from natural waters, and eggs and sperm are extruded without administration of hormones. However, the yield is not known and this approach requires a large number of females. Such large numbers are not available in France and we have tried to set up a reliable technique to induce ovulation 
and spermiation. Ovulation can be induced by the administration of carp pituitaries (Sorenson, et al., 1966) and partially purified salmon gonadotropin (PPSG) (De Montalembert et al., 1978a,b; Bry et al., 1978). Another salmon gonadotropin preparation (SG-G100) was shown to have effect on oocyte maturation (Jalabert et Breton, 1972). In the present work, we compare the efficiency of readily available preparations (carp and salmon pituitary extracts of known potency and PPSG) in inducing ovulation. In males, the volume of sperm spontaneously available for artificial insemination is usually low (Portal, 1947; Chimits, 1956; Preudhomme, 1975; Huet, 1976). De Montalembert et al (1978a) slightly increased spermiation with the injection of high doses of progesterone. Carp pituitary extracts have also been reported to stimulate spermiation (Anwand, 1963). The present experiment compares the efficiency of carp, salmon and pike pituitary, and PPSG on pike spermiation. In addition a superactive LRH analogue (synthetic gonadotropin releasing hormone) was used in an attempt to stimulate release of the endogenous pituitary hormone and subsequent gonad stimulation.

\section{MATERIAL AND METHODS}

Experiments were carried out at Jouy-en-Josas (France) in spring 1979. One- to two-year-old males and females were taken from ponds in "La Dombes". Mature animals were selected; males giving sperm and females with oocytes at the stage of germinal vesicle in a non-peripheral position (checked after ovarian biopsy). They were immediately transported to the laboratory (duration of the transport: $6 \mathrm{~h}$ ). Experiments started as soon as the fish arrived in the laboratory. The females were given the hormonal treatment before transportation. Experimental groups, usually of 5-10 fish, were kept in 100-1 tanks with running, recirculated water (flow rate $1 \mathrm{l} / \mathrm{min}$ ) and in complete darkness. Before handling fish were anesthetised in 2-4 Phenoxy-ethanol (Merck) $(0.5 \mathrm{ml} / \mathrm{l})$. After each handling fish were bathed in malachite green (Romeil) $1 \mathrm{ppm}$ for $30 \mathrm{~s}$.

\section{Stimulation of spermiation}

Thirteen groups of male pikes (average weight $300 \mathrm{~g}$ ) were formed and received the following treatments (see also Table I).

Group 1: one single intraperitoneal (IP) injection of saline $(1 \mathrm{ml} / \mathrm{kg}$ body weight).

Groups 2-3: one single IP injection of crude extract of fresh pike pituitary at the respective doses of 1.2 or $14 \mathrm{mg}$ (wet weight dissolved in $1 \mathrm{ml}$ of saline) per $\mathrm{kg}$ body weight. Donor pike were males taken from the same population as the experimental fish. Pituitaries were taken immediately after killing and kept for a few days at $-20^{\circ} \mathrm{C}$ until use. They were then thawed and ground in a homogenizer (10 strokes) immediately before injection. 
Groups 4-7: one IP injection of partially purified salmon gonadotropin (PPSG) having half of the biological activity (test of oocyte maturation) of pure s-GTH (B. Breton and B. Jalabert, personal communication, 1979). The method for purification of PPSG includes saline extraction of freeze-dried salmon (Oncorhynchus tschawytscha) pituitary glands in a Tris $0.05 \mathrm{M} \mathrm{NaCl}$ buffer followed by affinity chromatography on concanavaline A sepharose, according to Idler et al. (1975). This PPSG is more active than SG-G100 (Donaldson et al., 1972). The following doses were given: 5, 10, 20 and 100 $\mu \mathrm{g}$ (in $1 \mathrm{ml}$ of saline) per $\mathrm{kg}$ body weight.

Groups 8-10: one IP injection of a crude preparation of acetone-dried carp pituitary: respective doses $0.5,1.0$, and $3.0 \mathrm{mg} / \mathrm{kg}$ body weight. Content in pure c-GTH was respectively 17,34 , and $50 \mu \mathrm{g}$.

Groups 11-13: three successive intracardiac injections in $24 \mathrm{~h}$ of a 'superactive' LRH analogue (D-Trp6-des-Gly10) LH RH-Ethylamide, (LRHa) at the doses of $0.1,1$, and $10 \mu \mathrm{g} / \mathrm{kg}$ body weight per injection. The first injection was given at $23.00 \mathrm{~h}$ and the others 8 and $16 \mathrm{~h}$ later.

Except in groups 11, 12 and 13, the hormone injections were given in the morning. Before injection and at various intervals after (2-4 days) sperm was expelled by hand stripping and measured to the nearest $10 \mu \mathrm{l}$ with a $0.2-\mathrm{ml}$ pipette applied to the genital papilla. As the sperm comes out it is sucked with the mouth connected to the pipette by a hose. Measurements were carried out until the volume of sperm collected had decreased to the preinjection level. In group 1 (saline) sperm was collected over a period of 20 days. The number of spermatozoa collected was estimated by the spermatocrit method (De Montalembert et al., 1980). Briefly, hematocrit tubes were filled with sperm and centrifuged (12000 rpm for $20 \mathrm{~min}$ ): The number of șpermatozoa $(Y)$ is taken from the spermatocrit $(X)(Y=2.6368+0.45 X)$. Duration and intensity of sperm motility were established as given in De Montalembert et al. (1978a), and at least once during the period of treatment the fertilizing capacity of the sperm was measured for some groups. For this, artificial insemination and incubation were performed as previously described (Billard et al., 1976; De Montalembert et al., 1978a). Sperm dilution for artificial insemination was $10^{-3}$ and incubation of fertilized eggs was carried out in recirculated and thermoregulated water $\left(10 \pm 1^{\circ} \mathrm{C}\right)$ for 5 or 6 days. After this period, non-fertilized eggs and dead embryos become white and the percentage of embryos recorded after 5 or 6 days of incubation gives a good estimation of the surviving embryos. The percentage of developing eggs at $50-60^{\circ} \mathrm{C}$ degree-days was established after clearing in Stockard's fluid. Eggs used to test the fertilizing capacity of the sperm were obtained following treatment of the females with $50 \mu \mathrm{g} / \mathrm{kg}$ body weight of PPSG. Fertilization tests were carried out once in each group during the postinjection period and at different times for the various groups: therefore eggs were different and percentages of developing embryos are given with the control sperm taken from non-treated males. 


\section{Induction of ovulation}

Females used in the experiment (average weight $500 \mathrm{~g}$ ) were at a submature stage: end of vitellogenesis and nucleus still in a non-peripheral position. They were given the following treatments.

Group 1: one IP injection of saline, $1 \mathrm{mg} / \mathrm{kg}$ body weight.

Groups 2-3: one IP injection of freeze-dried salmon pituitaries: 10 and 2.5 $\mathrm{mg}$ (dry weight) per $\mathrm{kg}$ body weight. Each $\mathrm{mg}$ of crude pituitary contains 10 $\mu \mathrm{g}$ of purified s-GTH (Breton et al., 1978).

Groups 4-6: one IP injection of PPSG, as in male groups. Respective doses: 100,50 and $20 \mu \mathrm{g} / \mathrm{kg}$ body weight.

Groups 7-9: one IP injection of a crude preparation of acetone-dried carp pituitaries at the doses of 1,2 and $3 \mathrm{mg} / \mathrm{kg}$ body weight.

Group 10: one single injection of 'superactive' LRH analogue (LRHa) at the dose of $1 \mu \mathrm{g} / \mathrm{kg}$ body weight. The LRHa was mixed with $1 \mathrm{ml}$ olive oil, shaken and the emulsion was given intraperitoneally as previously reported by Aida et al. (1978).

Injections were given late in the morning at the time of capture and before transportation. This procedure was previously shown to give the best percentage of ovulation (De Montalembert et al., 1978b). Females kept at $10 \pm 1^{\circ} \mathrm{C}$ were checked for ovulation on the fourth day postinjection and every day after. On days 5 and 6 postinjection, non-ovulated females were checked for the stage of oocyte maturation (according to De Montalembert et al., 1978b) after squeezing some oocytes out of the genital papilla. Ovulated females were stripped, eggs were weighed and an aliquot of 300-500 eggs was fertilized according to the technique of artificial insemination refered to previously for the males. Sperm was taken from several males $(5-10)$ pooled and diluted at $1 / 1000$ at the time of insemination. The percentage of embryonated eggs was established as previously reported. All females, having ovulated or not, were killed on day 7 post-injection. Ovaries or remnants of ovaries were weighed. Ovulated eggs left in the lumen of the ovaries and in the oviducts were weighed and added to the weight of ovulated eggs. This allowed the calculation of the ovulation index: (weight of ovulated eggs/weight of ovulated eggs + remnant ovaries $X \cdot 100$ ).

\section{Statistical analysis}

The mean values in the tables are given with \pm SD. Comparisons for the production of sperm, spermatocrit and percentage of fertilization are made with variance analysis after angular transformation of the percentages. In male groups 11,12 and 13, percentages of fertilization are compared with $\chi^{2}$ test. 


\section{Stimulation of spermiation}

The total volume of sperm collected after the hormonal treatment is shown in Table I and Figs 1, 2 and 3. All pituitary extracts significantly stimulated sperm production in comparison with the saline group and most of the males exhibited a response which was proportional to the dose, and not related to the weight of the males. LRHa had no effect. The evolution of the production of sperm after pituitary treatment is shown in Figs. 1, 2; 3. With pike pituitaries, sperm production rose very quickly and the maximum response was recorded 2 days after injection. Sperm production decreased gradually until

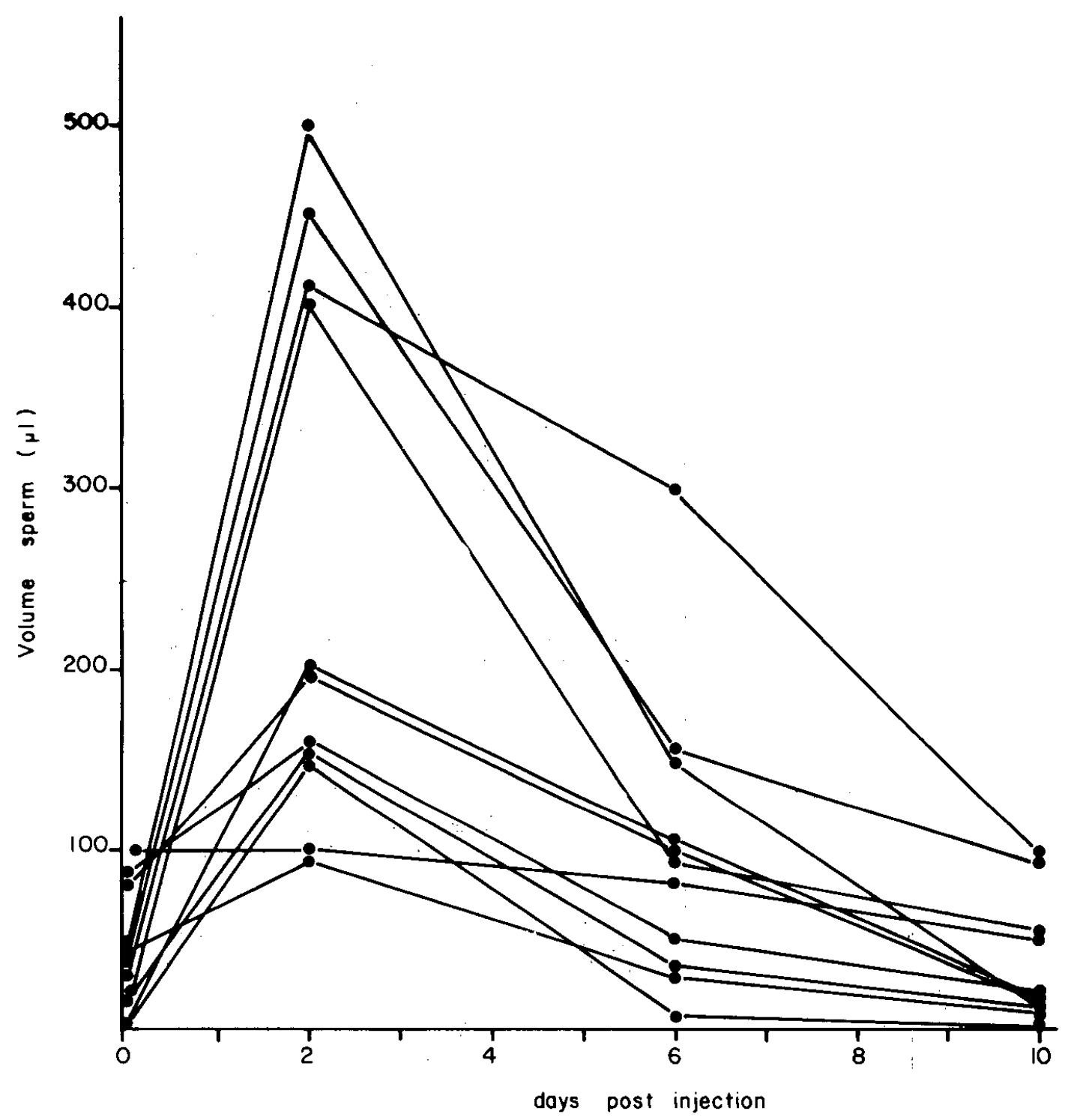

Fig. 1. The course of spermiation in pike following injection of crude pike pituitaries (14 $\mathrm{mg} / \mathrm{kg}$ body weight). 
TABLE I

Effects of pike and carp crude pituitary preparation, partially purified salmon gonadotropin (PPSG) and LRH analogue (LRHa) on spermiation in pike (Esox lucius)

\begin{tabular}{|c|c|c|c|c|c|c|c|c|c|c|}
\hline \multirow[t]{2}{*}{ Group } & \multirow[t]{2}{*}{ Treatment. } & \multirow{2}{*}{$\begin{array}{l}\text { Dose (per kg } \\
\text { b/w per } \\
\text { injection) }\end{array}$} & \multirow[t]{2}{*}{$n$} & \multirow{2}{*}{$\begin{array}{l}\text { Total volume } \\
\text { cf sperm }(\mu \mathrm{l}) \\
\left(\bar{X}^{-} \pm \text {SD }\right)\end{array}$} & \multirow{2}{*}{$\begin{array}{l}\text { Sperma- } \\
\text { tocrite } \\
\bar{X} \pm \text { SD }\end{array}$} & \multicolumn{2}{|c|}{$\begin{array}{l}\text { Number of sperma- } \\
\text { zoa collected }\end{array}$} & \multirow{2}{*}{$\begin{array}{l}\text { Duration } \\
\text { of re- } \\
\text { sponse } \\
\text { (days) }\end{array}$} & \multirow{2}{*}{$\begin{array}{l}\text { Fertilizing } \\
\text { capacity } \\
(\% \pm \mathrm{SD})\end{array}$} & \\
\hline & & & & & & $\begin{array}{l}\text { Total } \\
\left(\times 10^{9}\right)\end{array}$ & $\begin{array}{l}\bar{X} \text { per } \\
\text { day } \\
\left(\times 10^{6}\right)\end{array}$ & & & \\
\hline 1 & Saline & & 10 & $64 \pm \quad 55$ & $36 \pm 18$ & 1.22 & 61 & 20 & $90 \pm 100$ & \\
\hline 2 & Pike pituitary & $1.2 \mathrm{mg}^{1}$ & 10 & $385 \pm 283^{*}$ & $29 \pm 5$ & 4.31 & 431 & 10 & $82 \pm 4$ & \\
\hline 3 & Pike pituitary & $14 \mathrm{mg}^{1}$ & 11 & $540 \pm 393^{*}$ & $32 \pm 13$ & 9.20 & 657 & 14 & $67 \pm 23^{* 2}$ & \\
\hline 4 & PPSG & $5 \mu \mathrm{g}$ & 10 & $325 \pm 195 * *$ & $24 \pm 10^{*}$ & 4.39 & 439 & 10 & $23 \pm 9$ & \\
\hline 5 & PPSG & $10 \mu \mathrm{g}$ & 10 & $306 \pm 99 * *$ & $27 \pm 7 *$ & 4.58 & 458 & 10 & $46 \pm \quad 15$ & $\mathrm{NS}^{3}$ \\
\hline 6 & PPSG & $20 \mu \mathrm{g}$ & 10 & $368 \pm 177 * *$ & $25 \pm 7 *$ & 5.16 & 369 & 14 & $22 \pm 7$ & \\
\hline 7 & PPSG & $100 \mu \mathrm{g}$ & 10 & $972 \pm 341 * *$ & $25 \pm 9 *$ & 13.72 & 653 & 21 & $24 \pm 12$ & \\
\hline 8 & Carp pituitary & $0.5 \mathrm{mg}$ & 10 & $242 \pm 91 * *$ & $30 \pm 8$ & 3.95 & 482 & 14 & -4 & \\
\hline 9 & Carp pituitary & $1 \mathrm{mg}$ & 10 & $339 \pm 139 * *$ & $31 \pm 7$ & 5.62 & 401 & 14 & -4 & \\
\hline 10 & Carp pituitary & $3 \mathrm{mg}$ & 9 & $422 \pm 227 * *$ & $30 \pm 9$ & 6.87 & 491 & 14 & -4 & \\
\hline 11 & LRHa & $0.1 \mu \mathrm{g}^{6}$ & 10 & $41 \pm 20$ & $29 \pm 9$ & 0.63 & 90 & 7 & 100 & $* *$ \\
\hline 12 & LRHa & $1 \mu \mathrm{g}^{6}$ & 9 & $49 \pm 25$ & $29 \pm 13$ & 0.76 & 108 & 7 & 87 & 5 \\
\hline 13 & LRHa & $10 \mu g^{6}$ & 10 & $30 \pm 25$ & $26 \pm 14$ & 0.43 & 61 & 7 & 87 & NS \\
\hline
\end{tabular}

${ }^{1}$ Wet weight. ${ }^{2}$ Control: group $1 .{ }^{3}$ Control: $36 \pm 19 \%$ fertilization. ${ }^{4}$ Not determined (no eggs available). ${ }^{5}$ Sperm pooled and one determination; control $100 \%$ fertilization. ${ }^{6} 3$ injections. Comparison with variance analysis vs. controls, except in ${ }^{5} \chi^{2}$ test; $* P<0.005$; $* * P<0.001$. 

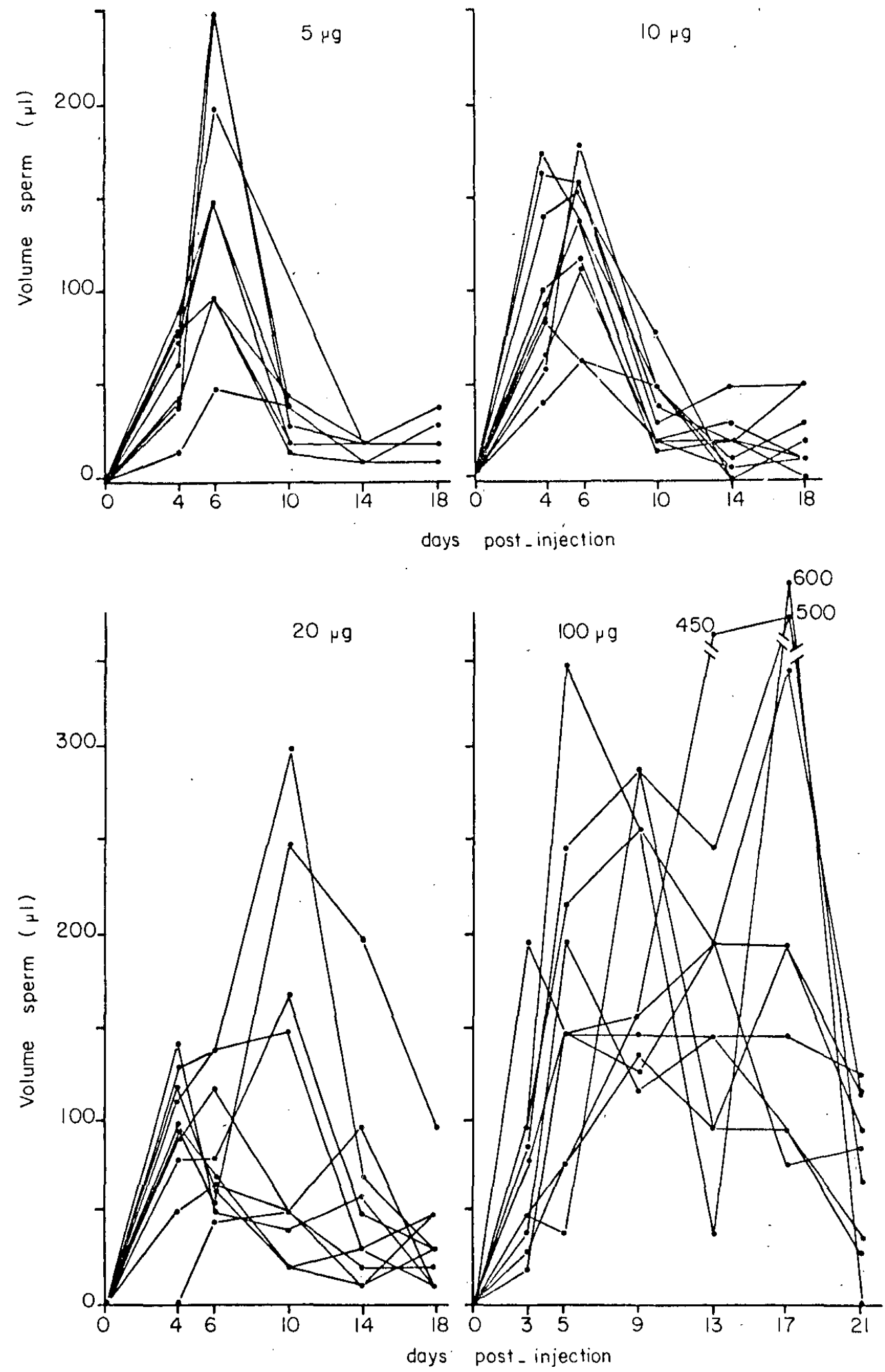

Fig. 2. The volume $(\mu \mathrm{l})$ of sperm collected after injection of partially purified salmon gonadotropin (doses: $5,10,20,100 \mu \mathrm{g} / \mathrm{kg}$ body weight). 

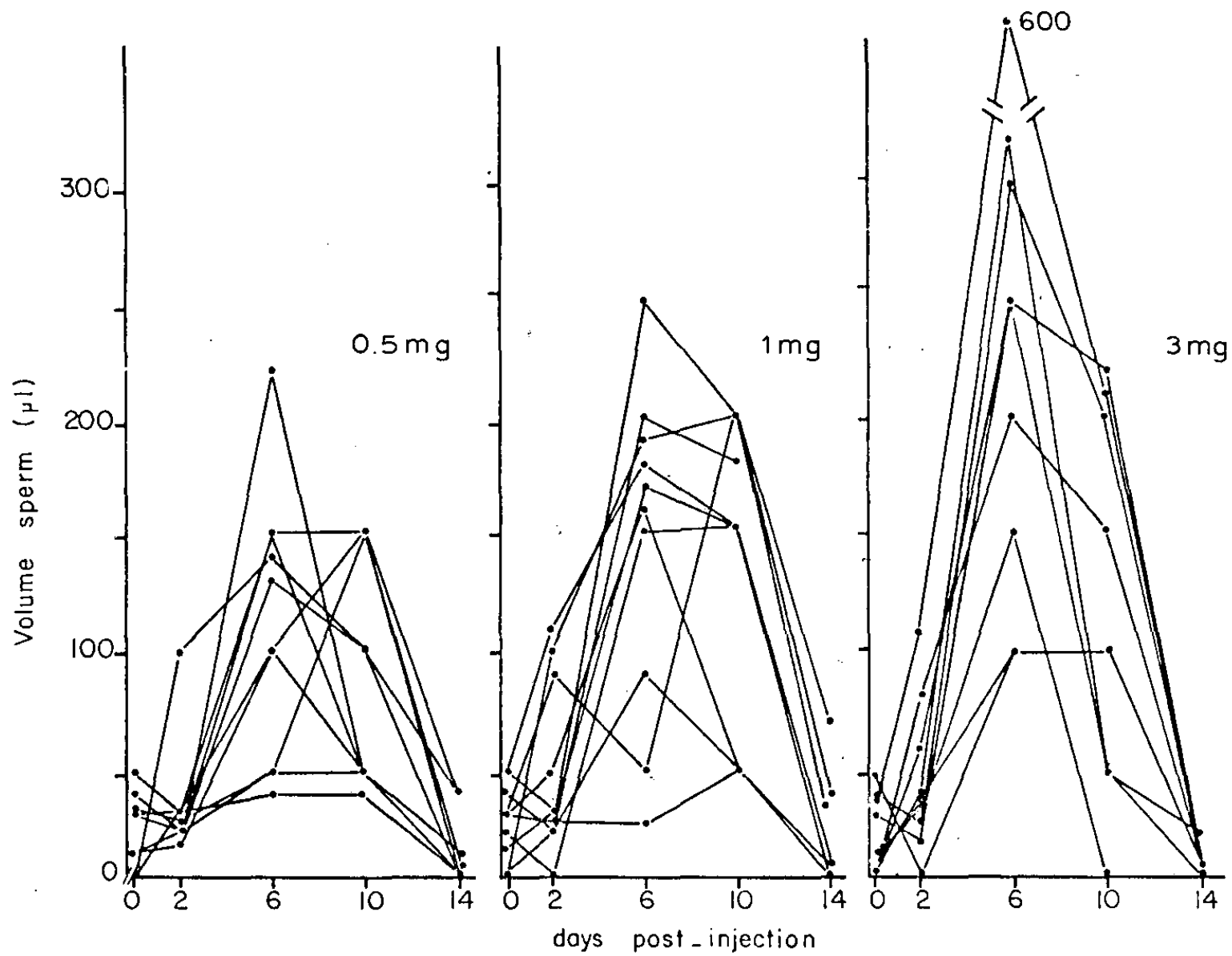

Fig. 3. The volume $(\mu \mathrm{l})$ of sperm collected after injection of crude extracts of carp pituitary gland (doses: $0.5,1,3 \mathrm{mg} / \mathrm{kg}$ body weight).

reaching the preinjection level after 10 days (Fig. 1). With PPSG (Fig. 2) maximum response occurred slightly later than with pike pituitaries: $4-6$ days. In the high-dose groups, 20 and $100 \mu \mathrm{g} / \mathrm{kg}$ body weight, sperm production showed strong fluctuations and duration of the response was slightly longer. Carp pituitary extracts also gave the maximum response 6 days postinjection, compared with 2 and 10 days. After 14 days, the sperm production was down to the preinjection level.

Spermatocrit was significantly lower than in controls (group $1, P<0.05$ ) in all groups treated with PPSG. Despite this, the absolute number of spermatozoa collected was strongly stimulated by the treatment with partially purified or crude pituitaries (Table I). The sperm fertilizing capacity was slightly depressed by the highest dose of pike pituitaries and LRHa $(P<0.001)$. In groups treated with PPSG, the fertilizing capacity.was tested with eggs of poor quality ( $36 \%$ of embryonated eggs in control fertilized with sperm from nontreated males) and was not significant in comparison with controls.

\section{Induction of ovulation (Table II)}

In the saline group no ovulation was detected between days 4 and 7 and no oocyte maturation was observed following examination of the follicle at au- 


\section{TABLE II}

Effect of salmon and carp pituitaries, partially purified salmon gonadotropin (PPSG) and LRH analogue (LRHa) on ovulation in pike (Esox lucius)

\begin{tabular}{|c|c|c|c|c|c|c|c|c|c|c|c|c|}
\hline \multirow[t]{2}{*}{ Group } & \multirow[t]{2}{*}{ Treatment } & \multirow[t]{2}{*}{$\begin{array}{l}\text { Dose } \\
(\mathrm{mg} / \mathrm{kg})\end{array}$} & \multirow[t]{2}{*}{$\begin{array}{l}\text { Equivalent } \\
\text { GTH }\end{array}$} & \multirow[t]{2}{*}{$n$} & \multicolumn{2}{|c|}{ Non ovulated } & \multicolumn{2}{|c|}{$\begin{array}{l}\text { Partially } \\
\text { ovulated }\end{array}$} & \multicolumn{2}{|c|}{$\begin{array}{l}\text { Completely } \\
\text { ovulated }\end{array}$} & \multirow{2}{*}{$\begin{array}{l}\text { Mean } \\
\text { ovula- } \\
\text { tion } \\
\text { index }\end{array}$} & $\begin{array}{l}\text { Fertilization } \\
(\%) \pm \text { SD }\end{array}$ \\
\hline & & & & & $n$ & $\begin{array}{l}\text { Oocyte } \\
\text { matu- } \\
\text { ration }\end{array}$ & $n$ & $\begin{array}{l}\text { Ovula- } \\
\text { tion } \\
\text { index } \\
\text { s }^{3}\end{array}$ & $n$ & $\begin{array}{l}\text { Ovula- } \\
\text { tion } \\
\text { index }\end{array}$ & & \\
\hline 1 & Saline & - & - & 5 & 5 & 0 & 0 & & 0 & & 0 & \\
\hline 3 & $\begin{array}{l}\text { Salmon } \\
\text { pituitary }\end{array}$ & 2.5 & $25^{1}$ & 8 & 6 & + & 0 & & 2 & $\begin{array}{l}77 \\
(76-79)\end{array}$ & 77 & $63 \pm 35^{\mathrm{NS}}$ \\
\hline 4 & PPSG & 0.1 & $50^{1}$ & 9 & 0 & & 1 & 12 & 8 & $\begin{array}{l}86 \\
(68-93)\end{array}$ & 78 & $65 \pm 24$ NS \\
\hline 5 & PPSG & 0.05 & $25^{1}$ & 5 & 0 & & 0 & & 5 & $\begin{array}{l}87 \\
(63-94)\end{array}$ & 87 & $72 \pm 8$ \\
\hline 6 & PPSG & 0.02 & $10^{1}$ & 6 & 6 & - & 0 & & 0 & & 0 & \\
\hline 10 & LRHa & 0.001 & - & 10 & 10 & 0 & 0 & & 0 & & 0 & \\
\hline
\end{tabular}

${ }^{1}$ Equivalent s-GTH (salmon gonadotropin). ${ }^{2}$ Equivalent c-GTH (carp gonadotropin). ${ }^{3}$ Extreme values. 
topsy on day 7. With salmon pituitaries and PPSG, the effect of the hormonal treatment on ovulation was dependent on the dose given. At a high dose of salmon pituitaries ( $10 \mathrm{mg} / \mathrm{kg}$ body weight, equivalent to $100 \mu \mathrm{g}$ of pure s-GTH) all females exhibited signs of ovulation but two showed complete ovulation (79\% of the eggs were ovulated) and five were partially ovulated (30\% of the eggs). With $0.1 \mathrm{mg}$ PPSG (equivalent to $50 \mu \mathrm{g}$ of s-GTH) one female out of nine partially ovulated (12\%). At a low dose, $10 \mu \mathrm{g} \mathrm{s}$-GTH (group 6) neither ovulation nor oocyte maturation occurred. The most efficient doses were 25 and $50 \mu \mathrm{g} \mathrm{s}-\mathrm{GTH}$ (100 and $50 \mu \mathrm{g}$ PPSG), and these induced complete ovulation in most of the treated females. The fertility of the eggs was not significantly different (intra-group variance analysis) in groups treated with salmon pituitaries and PPSG.

Carp pituitary extract treatment was not so effective as salmon preparations. At $3 \mathrm{mg} / \mathrm{kg}$ body weight, only three females out of seven exhibited complete ovulation. Lower doses gave partial ovulation or no ovulation; oocyte maturation did however, occur. Eggs obtained after induction of ovulation with the highest doses of carp pituitaries had a significantly lower percentage of fertilization $(P<0.01)$ in comparison with the lower dose.

\section{DISCUSSION}

\section{Stimulation of spermiation}

Injection of gonadotropin preparations of various species including pike, salmon and carp strongly stimulated spermiation in pike. The volume of sperm was significantly increased after treatment. Although there were slight differences in spermatocrit, the absolute number of spermatozoa collected was also increased, except in one case. The fertilizing capacity of sperm was not significantly different from the control so that spermatozoa obtained after hormonal treatment are of a satisfactory quality.

The dynamics of sperm production following a single injection of gonadotropin preparation, shown in Figs 1,2 and 3, suggest that the response to treatment was faster and of shorter duration with pike pituitary. Response to treatment with salmon and carp pituitary preparations increased between days 4 and 6 whereas there was a decrease before day 6 following pike pituitary treatment. The concentration of GTH in donor pike pituitary is not known, so the amount injected cannot be established; it is known only that on a dry weight basis the amount of pike pituitary injected is less than with salmon and carp. This may reflect differences in the biological potency of GTH and suggest a phenomenon of zoological species specificity. Similarly, at equal doses of more purified GTH, PPSG is more potent than carp suggesting also differences in the potency of GTH. In that case, it should also be mentioned that the duration of the response is proportional to the dose with PPSG but not with carp pituitaries. This points out a possible species specificity which is discussed in the case of induction of ovulation (see below). Pitu- 
itary preparations used in the present experiment were much more efficient than progesterone previously used to stimulate spermiation (De Montalembert et al., 1978a).

\section{Induction of ovulation}

Salmon pituitary preparations, especially the partially purified one, can induce ovulation in pike provided the dose is adequate. From this study, the optimum dose is $25-50 \mu \mathrm{g} / \mathrm{kg}$ body weight of pure s-GTH (Breton et al., 1978). Salmon pituitary preparation (PPSG) was previously successfully used to induce ovulation in pike by De Montalembert et al. $(1978 a, b)$, who used a higher dose $(100 \mu \mathrm{g} / \mathrm{kg}$ body weight), but their batch of PPSG was only half as potent as the one employed in the present experiment (B. Breton, personal communication, 1979). The lowest dose of PPSG (20 $\mu \mathrm{g} / \mathrm{kg}$ body weight) had no effect on ovulation; this indicates that a minimum amount of GTH is required to obtain ovulation, as already observed in pike (De Montalembert et al., 1978b). However, the biological activity of the mixture should be known since ovulation was not always complete at the highest dose administered. An apparent inhibitory effect was observed with crude material; this may be due to other pituitary factors or neurohormones present in the crude extract. Results obtained with carp pituitary are interesting because treatment was less effective. The highest dose of $3 \mathrm{mg} / \mathrm{kg}$ (equivalent to $50 \mu \mathrm{g}$ pure c-GTH) induced ovulation in three females out of seven treated, and the eggs obtained had a poor fertilizing rate (8\%). This may be due to the fact that ovulation was atypical with remnants of follicles around the eggs. At a low dose partial ovulation or no ovulation at all occurred but in all cases oocyte maturation was observed. It appears therefore that at the dose usually employed to induce ovulation in carp ( $3 \mathrm{mg} / \mathrm{kg}$ body weight) carp pituitaries do not always induce complete ovulation in pike and the quality of eggs is very poor. This may be related to the problem of a zoological species specificity of GTH which was shown to be very strong on gametogenesis (Breton et al., 1973) but also in oocyte maturation and ovulation (Jalabert et al., 1974). When compared to PPSG, carp pituitaries have obviously a much lesser effect either quantitatively (on ovulation) or qualitatively (on fertility). In that respect s-GTH seems to be more closely related to pike GTH than to c-GTH. There is one paper (Sorenson et al., 1966) and many field reports or oral communications claiming that carp pituitaries are potent in inducing ovulation in pike but accurate data on doses used, stage of oocyte maturation, rate of ovulation and fertilization are usually not provided. Higher doses may be more efficient (G. Hristic, personal communication, 1979), but in addition to a higher cost such high doses include a risk of interference with other factors, as discussed above for crude salmon pituitaries. This inconvenience can be overcome by the use of a more purified material and even pure c-GTH. This requires more investigation, and the practical problem of the availability of c-GTH remains. 
The problem of LRHa inefficiency in stimulating $G T H$ release and ovulation in fish

A superactive LRH analogue (D-Ala ${ }^{6} \mathrm{EA}-\mathrm{LH}-\mathrm{RH}$ ) was successfully used to induce ovulation in grass carp (Cooperative Team for Hormonal Application in Pisciculture, 1977; The Polypeptide Group, 1976, 1977). Another one used in the present experiment had no effect on either ovulation or spermiation in pike. In the case of ovulation, failure might be due to the route and mode of administration which were based on Aida et al. (1978), who showed that LRH emulsified in Freund adjuvant and given IP induced oocyte maturation (hydratation) and ovulation in the plaice and the goby. The Polypeptide Group (1977) also used successfully an LRH in oil emulsion to induce spawning in Chinese carp. Another reason for the lack of success of the LRHa in pike might be because a big GTH ovulatory surge is required as in cyprinids (goldfish: Stacey et al., 1979), in which spawning is strongly influenced by temperature (Billard and Breton, 1978; Billard et al., 1978). The amount of GTH release, if any, was probably insufficient since there was no sign of oocyte maturation. In the male, three intracardiac doses in saline solution $8 \mathrm{~h}$ apart were also ineffective in stimulating spermiation. Usually no or a low threshold level of gonadotropin is needed to induce spermiation in males, and the response is proportional to dose (Clemens and Grant, 1965; Yamazaki and Donaldson, 1968). The treatment of these fish with gonadotropic preparations induced spermiation and oocyte maturation, and the lack of LRHa effect indicated an insufficient stimulation of pituitary gonadotropin release. It should be added that GTH was present in the pituitaries taken from males belonging to the same population (Table I). The lack of superactive LRH response is disappointing in view of the fact that LRH stimulates GTH secretion either in vitro or in vivo in trout and carp (Breton and Weil, 1973; Crim et al., 1976; Weil et al., 1978; Crim and Evans, 1979). However, stimulation of GTH secretion is usually low and probably not sufficient to induce ovulation in those species which require a large ovulatory GTH surge and are extensively cultured.

Only in a few cases, was LRH reported to have induced ovulation (Hirose and Ishida, 1974; plaice and goby; The Polypeptide Hormone Group, 1976, 1977; Conference on Application of Hormones to Economic Fish, 1975; Chinese carp). In the case of the Chinese carp, the only fish farmed currently, there was a response under culture conditions which allowed the process to continue to oviposition. The fish were not stripped and they spawned spontaneously; after LRH or LRHa injections, female and male carp were placed in a large circular tank with running water which mimicked the natural environment at spawning. It may be that a facilitating effect, due to this semi-natural environment, helped ovulation. LRH may influence sex behaviour, as shown in rats (Moss and McCann, 1973; Pfaff, 1973; Moss, 1977).

It should be pointed out that because of its great potential for reproduction induction in fish, LRH has been tested frequently in the last 10 years, but with limited success. Some of the reasons for failure are indicated above, but 
there are others. The effectiveness of LRH in inducing ovulation varies seasonally, as shown in goldfish (Lam et al., 1978), carp (Weil et al., 1975) and trout (Weil et al., 1978), and the time of treatment must be taken into consideration. Also, LRH and the agonistic analog may have a direct inhibitory effect on the gonads, as reported in fish (R.E. Peter et al., unpublished data) and in mammals, after short-term (Corbin et al., 1978; Hsueh and Erickson, 1979) or long-term (Amundson and Wheaton, 1979) treatment. It is also possible that giving $\mathrm{LRH}$ intraperitoneally or intravenously is not a good mode of administration because in most teleost species studied so far, there is no welldeveloped portal blood system, and the neurohormones reach the pituitary directly by nerve endings on the pituitary secretory cells. In addition, a phylogenetic specificity has been suggested between LRH and teleost Gn-RH (Breton and Weil, 1973; Crim and Cluett, 1974; Deery, 1974; Lam et al., 1975, 1976; Weil and Breton, 1976). The route of administration and species specificity may explain the large doses used to obtain ovulation in fish with LRH. The prospect of using LRH or LRHa as a substitute for pituitary preparation or GTH is not very promising at the moment.

\section{ACKNOWLEDGEMENTS}

We express our appreciation to Drs C.M. Campbell and L.W. Crim who commented on and improved the English presentation of the manuscript. Thanks are due to Gilles de Montalembert for helping to transport the fish and to Chantal Brachet for technical assistance. We also thank Dr. Breton for the gift of PPSG and M. Bell, Coopérative des Dombes, who provided us with the pike used in this experiment. This work was supported by a grant from the Conseil Supérieur de la Pêche. We thank Dr. Delsol for the interest he showed in this work.

\section{REFERENCES}

Aida, K., Izumo, R.S., Satoh, H. and Hibiya, M., 1978. Induction of ovulation in plaice and goby with synethetic LH releasing hormone. Bull. Jpn. Soc. Sci. Fish., 44: 445-450.

Amundson, B.C. and Wheaton, J.E., 1979. Effects of chronic LHRH treatment on brain LHRH content; pituitary and plasma LH and ovarian follicular activity in the anestrous ewe. Biol. Reprod., 20: 633-638.

Anwand, K., 1963. Die Wirkung von Hypophysen und Gonabioninjektionen auf Hechtmilchner. Dtsch. Fisch. Ztg., 10: 202-207.

Billard, R. and Breton, B., 1978. Rhythms of reproduction in teleost fish. In: J.E. Thorpe (Editor), Rhythmic Activity of Fishes. Academic Press, London, New York, NY San Francisco, Calif., pp. 31-53.

Billard, R., Debruille, M., Gerard, J.P. and De Montalembert, G., 1976. L'insémination artificielle du Broćhet. Bull. Fr: Pisc., 262: 30-34.

Billard, R., Breton, B., Fostier, A., Jalabert, B. and Weil, C., 1978. Endocrine control of the teleost reproductive cycle and its relation to external factors: salmonid and cyprinid models. In: P.J. Gaillard and H.H. Boer (Editors), Comparative Endocrinology. Elsevier/ North Holland, Biochemical Press, Amsterdam, pp. 37-48. 
Breton, B. and Weil, C., 1973. Effets d'extraits hypothalamiques de carpe et de LH-FSHRH de synthèse sur la sécretion d'hormone gonadotrope c-GTH, in vivo chez la carpe Cyprinus carpio. C.R. Acad. Sci. Paris, série D, 277: 2061-2064.

Breton, B., Billard , R. and Jalabert, B., 1973. Spécificité d'action et relations immunologiques des hormones gonadotropes de quelque téléostéens. Ann. Biol. Anim. Biochim. Biophys., 13: 347-362.

Breton, B., Prunet, P. and Reinaud, P., 1978. Sexual differences in salmon gonadotropin. Ann. Biol. Anim. Biochim. Biophys., 18: 759-765.

Bry, C., Billard, R. and De Montalembert, G., 1978. Induction de la maturation ovocytaire et de l'ovulation par traitement hormonal chez le brochet (Esox lucius). Bull. Fr. Pisc., 271: 21-32.

Chimits, P., 1956. Le brochet. Bull. Fr. Pisc., 180: 81-96.

Clemens, H.P. and Grant, F.B., 1965. The seminal thinning response of carp (Cyprinus carpio) and rainbow trout (Salmo gairdneri) after injections of pituitary extracts. Copeia, 2: $174-177$.

Conference on Application of Hormones to Economic Fish, 1975. Experiments on inducement of spawning in domestic fish by injection of synthesized luteinizing hormonereleasing hormone (LH-RH). Kexue Tongbao, 20: 43-48. (Translation Series No. 4186 FMS.)

Cooperative Team for Hormonal Application in Pisciculture, 1977. A new highly ef fective ovulating agent for fish reproduction. Practical application of LH-RH analogue for the induction of spawning of farm fishes. Scientia Sinica, XX: 469-474.

Corbin, A., Beattie, C.W., Tracy, J., Jones, R., Foell, T.J., Yardley, J. and Rees, R.W.A., 1978. The anti-reproductive pharmacology of LH-RH and agonistic analogues. Int. J. Fertil., 23: 81-92.

Crim, L.W. and Cluett, D.M., 1974. Elevation of plasma gonadotropin concentration in response to mammalian gonadotropin releasing hormone (GRH) treatment of the male brown trout as determined by radioimmunoassay. Endocrinol. Res. Commun., 1: 101110.

Crim, L.W. and Evans, D.M., 1979. LH-RH stimulated gonadotropin release from the rainbow trout pituitary gland; an in vitro assay for teleost gonadotropin releasing factor(s). Gen. Comp. Endocrinol. 40: 283-290.

Crim, L.W., Peter, R.E. and Billard, R., 1976. Stimulation of gonadotropin secretion by intraventricular injection of hypothalamic extracts in the goldfish Carassius auratus. Gen. Comp. Endocrinol., 30: 77-82.

Deery, D.J., 1974. Determination by radioimmunoassay of the luteinising hormone-releas ing hormone (LH-RH) content of the hypothalamus of the rat and some lower vertebrates. Gen. Comp. Endocrinol., 24: 280-285.

De Montalembert, G., Bry, C. and Billard, R., 1978a. Control of reproduction in northern pike. Am. Fish. Soc. Spec. Publ., 11: 217-225.

De Montalembert, G., Jalabert, B. and Bry, C., 1978b. Precocious induction of maturation and ovulation in northern pike (Esox lucius). Ann. Biol. Anim. Biochim. Biophys., 18: 969-975.

De Montalembert, G., Marcel, J. and Billard, R., 1980. La spermiation chez le Brochet. I - Evolution de la quantité de sperme récolté au cours de la saison de reproduction. Bull. Fr. Piscic., 276: 90-103.

Donaldson, E.M., Yamazaki, F., Dye, H.M. and Philleo, W.W., 1972. Preparation of gonadotropin from salmon (Oncorhynchus tschawytscha) pituitary glands. Gen. Comp. Endocrinol., 18: 469-481.

Hirose, K. and Ishida, R., 1974. Induction of ovulation in the Ayu, Plecoglossus altivelis, with LH-releasing hormone (LH-RH). Bull. Jpn. Soc. Sci. Fish., 40: 1235-1240.

Hsueh, A.J.W. and Erickson, G.F., 1979. Extrapituitary action of gonadotropin releasing hormone: direct inhibition of ovarian steroidogensis. Science, 204: 854-855.

Huet, M., 1976. Reproduction, incubation et alevinage du Brochet, Esox lucius. EIF AC, Tech. Pap., 25: 147-163. 
Idler, D.R., Bazar, L.S. and Hwang, J.S., 1975. Fish gonadotropin(s). II - Isolation of gonadotropin(s) from chum salmon pituitary glands using affinity chromatography. Endocrinol. Res. Commun., 2: 215-235.

Jalabert, B. and Breton, B., 1972. In vitro ovulation of pike (Esox lucius) oocytes. Gen. Comp. Endocrinol., 22: 391, (abstract).

Jalabert, B., Breton, B. and Billard, R., 1974. Dosage biologique des hormones gonadotropes de poissons par le test de maturation in vitro des ovocytes de truite. Ann. Biol. Anim. Biochim. Biophys., 14: 217-228.

Lam, T.J., Pandey, S. and Hoar, W.S., 1975. Induction of ovulation in goldfish by synthetic luteinizing hormone releasing hormone LH-RH. Can. J. Zool., 53: 1189-1192.

Lam, T.J., Pandey, S., Nagahama, Y. and Hoar, W.S., 1976. Effects of synthetic luteinizing hormone releasing hormone (LH-RH) on ovulation and pituitary cytology of the goldfish Carassius auratus. Can. J. Zool., 54: 816-824.

Lam, T.J., Pandey, S., Nagahama, Y., Hoar, W.S., 1978. Endocrine control of oogenesis, ovulation and oviposition in goldfish. In: P.J. Gaillard and H.H. Boer (Editors), Comparative Endocrinology. Elsevier/North Holland, Biochemical Press, Amsterdam, pp. 55-64.

Moss, R.L., 1977. Role of hypophysiotropic neurohormones in mediating neural and behavioural events. Fed. Proc., 36: 1978-1983.

Moss, R.L. and McCann, M., 1973. Induction of mating behavior in rats by luteinizing hormone-releasing factor. Science, 181: 177-197.

Pfaff, D.W., 1973. Luteinizing hormone-releasing factor potentiates lordosis behavior in hypophysectomized ovariectomized female rats. Science, $182: 1148-1149$.

Portal, J., 1947. Observations sur la pisciculture artificielle du Brochet. Bull. Fr. Pisc., 147 : $61-70$.

Preudhomme, J.G., 1975. Troubles sexuels resultant de l'acclimatation chez les poissons, notamment Brochet et Truite arc-en-ciel. Pisc. Fr., 43: 38-46.

Sorenson, L., Buss, K. and Bradford, A.D., 1966. The artificial propagation of esocid fishes in Penssylvania. Prog. Fish Cult., 28: 133-141.

Stacey, N.E., Cook, A.F. and Peter, R.E., 1979. Ovulatory surge of gonadotropin in the goldfish Carassius auratus. Gen. Comp. Endocrinol., 37: 246-249.

The Polypeptide Group, 1976. The stimulatory effect of a synthetic analogue of hypothalamic luteinizing hormone releasing hormone (LRH) on spawning in "domestic fishes". Acta Biochim. Biophys. Sinica, 8: 107-114.

The Polypeptide Group, 1977. A further investigation on the stimulatory effect of a synthetic analogue of hypothalamic luteinizing hormone releasing hormone (LRH A) on spawning in "domestic fishes". Acta Biochim. Biophys. Sinica, 9: 15-24.

Weil, C. and Breton, B., 1976. Différence d'action in vivo du LH-RH et d'un extrait hypothalamique de poisson chez la Carpe. INSERM, Coll. de Synthèse, Série Action Thématique, 7: 293-299.

Weil, C., Breton, B. and Reinaud, P., 1975. Etude de la réponse hypophysaire à l'administration de Gn-RH exogène au cours du cycle reproducteur annuel chez la Carpe Cyprinus carpio. C.R. Acad. Sci. Paris, série D, 280: 2469-2472.

Weil, C., Billard, R., Breton, B. and Jalabert, B., 1978. Pituitary response to LH-RH at different stages of gametogenesis in the rainbow trout (Salmo gairdneri). Ann. Biol. Anim. Biochim. Biophys., 18: 863-869.

Yamazaki, F. and Donaldson, E.M., 1968. The spermiation of goldfish (Carassius auratus) as a bioassay for salmon (Oncorhynchus tschawytscha) gonadotropin. Gen. Comp. Endocrinol., 10: 383-391. 